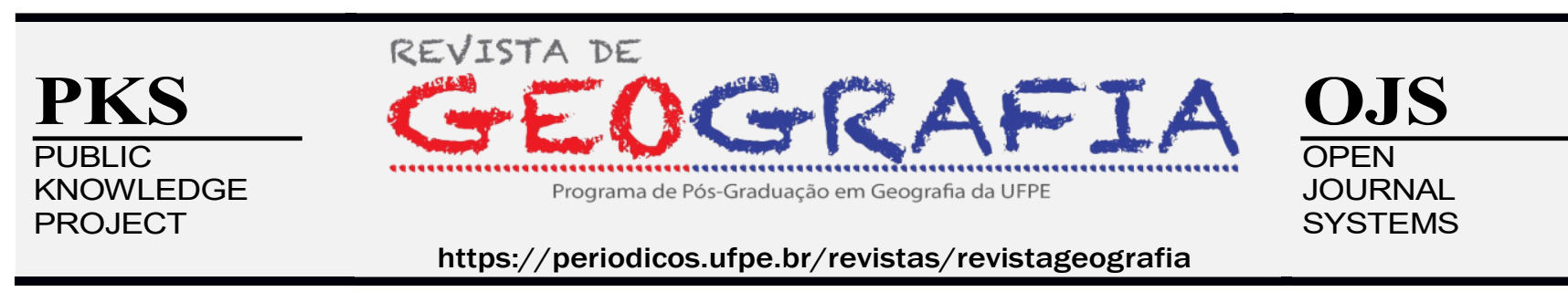

\title{
QUAL COMUNIDADE CONSTRUIR? BELISÁRIO, UM DISTRITO NA MIRA DE UMA GRANDE MINERADORA
}

\author{
Gabriel Max de Oliveira Dias ${ }^{1}$, Ivair Gomes ${ }^{2}$, Arlon Cândido Ferreira ${ }^{3}$, Luiz Renato Vallejo ${ }^{4}$
}

${ }^{1}$ Universidade Federal de São João del-Rei.E-mail: gabriel_ervalia@yahoo.com.br.Orcid: http://orcid.org/0000-00024250-4851

${ }^{2}$ Universidade Federal de São João del-Rei. E-mail: ivair@ufsj.edu.br.Orcid: http://orcid.org/0000-0002-5897-5084

${ }^{3}$ Universidade Federal Fluminense. E-mail: arloncf@gmail.com. Orcid: http://orcid.org/0000-0003-0075-7989

${ }^{4}$ Universidade Federal Fluminense.E-mail: luizrenato@id.uff.br. Orcid: http://orcid.org/0000-0002-2411-7436

Artigo recebido em 05/04/2021 e aceito em 12/09/2021

\section{RESUMO}

Este trabalho tem como tema a possibilidade de início da atividade mineradora no distrito de Belisário/MuriaéMG. A mineração já é uma realidade em outros municípios da região, sendo realizada pela Companhia Brasileira de Alumínio. A partir de 2016 o atrito entre a empresa e a comunidade se acirrou, pois cresceu no distrito um movimento contrário ao empreendimento. Muitos moradores defenderam que o projeto impactaria negativamente a realidade do distrito, principalmente no tocante a agricultura familiar, ao turismo e a preservação ambiental. A mobilização comunitária obteve a atenção e o apoio externo, resultando em visibilidade que conseguiu transformar o distrito em Patrimônio Hídrico Municipal no ano de 2018. O fato se constituiu numa estratégia para impedir o começo da atividade minerária. Este trabalho buscou compreender a visão dos mais jovens sobre os acontecimentos na comunidade e foi focado nos alunos do $1^{\circ}$ e $2^{\circ}$ ano do Ensino Médio da escola localizada na sedo do distrito, relacionamento suas expectativas de vida com o projeto de território que eles visam construir e a visão que eles possuem sobre o lugar. Ao final, constatou-se que, para estes jovens, a mineração é uma ameaça sendo mais viável que a comunidade siga suas potencialidades vigentes.

Palavras-chave: Mineração; Território; Lugar.

\section{WHICH COMMUNITY TO BUILD? BELISÁRIO, A DISTRICT IN THE SITES OF A LARGE MINING COMPANY}

\begin{abstract}
This work has its theme the possibility of starting mining activity in the district of Belisário/Muriaé-MG. Mining is al ready a reality in other municipalities in the region, being carried out by Brazilian Aluminun Company. As of 2016, the friction between the company and the community intensified, as a movement Against the enterprise grew in the district. Many residentes argued that the project would negatively impact the reality of the district, especially with regard to family farming, tourism and environmental preservation. The community mobilization got the attention and external support, resulting in visibility that managed to
\end{abstract}


transform the district into Municipal Water Heritage in 2018. The fact was a strategy to prevent the beginning of mining activity. This work sought to understand the vision of the voungest about the events in the Community and was focused on students from the 1st and 2nd year of high school at the school located at the district headquarters, relating their life expectations to the territory project that They aim to build and their view of the place. In the end, it was found that for these Young people, mining is a threat and it is move viable for the Community to follow its current potencial.

Keywords: Mining. Territory. Place.

\section{INTRODUÇÃO}

\section{A comunidade do Belisário}

Belisário é um distrito de Muriaé-MG, localizado aproximadamente a $35 \mathrm{~km}$ da sede municipal, sendo que $16 \mathrm{~km}$ se dá por estrada sem pavimentação. $\mathrm{O}$ distrito abriga, segundo o último censo demográfico (IBGE, 2010) 2.327 habitantes, sendo 1.028 vivem em sua sede (urbano) e 1.299 no seu entorno (rural) e apresenta uma altitude elevada em relação ao restante do município.

A paisagem urbana do distrito é repleta de elementos que remetem ao rural. Os estabelecimentos comerciais como mercados, farmácias e lojas de material de construção, se misturam com o constante fluxo de tratores, cavalos e charretes. Arquitetonicamente predominam casas com janelas voltadas diretamente para a rua e grandes quintais que, muitas vezes, se juntam à pastagem e deixa perceptível o perfil agrícola do distrito.

Na zona rural a presença de casas espalhadas marca a existência de pequenas propriedades, ao mesmo tempo que são observadas, de forma descontínua, algumas fazendas maiores. Tais territórios são utilizados principalmente para pastagem, silvicultura e cafeicultura, sendo a última marcante nas pequenas propriedades com seus terrenos íngremes, onde parece ser impossível uma mecanização generalizada.

Belisário é o único distrito de Muriaé que abriga o Parque Estadual Serra do Brigadeiro, que se estende pelos municípios de Rosário de Limeira, Ervália, Miradouro, Fervedouro, Pedra Bonita, Araponga, Canaã, Sericita e Divino, todos na Zona da Mata Mineira. Além do parque, Belisário abriga outra Unidade de Conservação, a Área de Proteção Ambiental Municipal do Pico do Itajurú (APA - Pico do Itajuru), onde seus atrativos vêm sendo utilizados por moradores e pelo poder público para incentivar a atividade turística, contanto com pousadas, restaurantes, guias turísticos, serviços de passeios em quadriciclo, entre outros serviços voltados para o setor. 


\section{UM DISTRITO NA MIRA DE UMA GRANDE MINERADORA}

Os relatos de moradores da comunidade indicam que a realização dessas atividades econômicas é histórica, entretanto, quando a mineradora Companhia Brasileira de Alumínio (CBA), empresa do grupo Votorantim começou a realizar estudos sobre a viabilidade da exploração de Bauxita no município, surgiram possibilidades de mudanças, especialmente no distrito de Belisário.

Atualmente a empresa já explora o mineral em municípios vizinhos, como São Sebastião da Vargem Alegre, Miraí e Itamarati de Minas e detém 23 direitos minerários no município de Muriaé, concedidos pelo Departamento Nacional de Produção Mineral (DNPM). Entretanto, Krakovics (2017) em nota publicada no jornal O Globo afirmou que a empresa não tinha planos de explorar o minério nos próximos 5 anos no distrito. Ao contrário Dotta (2018), em reportagem publicada no Jornal Brasil de Fato relata o seguinte:

A CBA tem abertos 27 requerimentos de lavra para minerar a Zona de Amortecimento do Parque Estadual Serra do Brigadeiro e entorno. Se forem aprovados, a mineração irá minerar três Áreas de Proteção Ambiental: A APA Municipal Pico do Itajurú (Muriaé), APA Municipal Serra das Aranhas (Rosário de Limeira) e APA Municipal Rio Preto (São Sebastião da Vargem Alegre). (DOTTA, 2018, p. 5).

A partir de 2016 a mobilização com o intuito de evitar a entrada da mineração ganhou força, principalmente com a atuação do Frei Gilberto Teixeira da Silva que ao assumir a paroquia do distrito e tomar ciência da possibilidade do início da operação da mineradora, passou a promover espaços de discussão sobre o tema.

A situação de Belisário ganha visibilidade nacional quando em 19 de fevereiro de 2017, logo após uma missa, um homem armado empurrou o frei para dentro da casa paroquial e o ameaçou de morte caso ele insistisse em abordar o assunto durante as celebrações religiosas. $\mathrm{O}$ fato foi divulgado por grandes grupos midiáticos sendo repercutido por políticos, pela Diocese de Leopoldina-MG, por diversos movimentos sociais, entre outros, até que em 26 de junho de 2017 o religioso foi incluído em um programa de proteção da Secretaria de Estado de Direitos Humanos, Participação Social e Cidadania, visando garantir sua integridade física.

Na época dos acontecimentos, a CBA, por meio de nota divulgada pelo Portal de Notícias G1 (2017), negou a participação no ato de violência, afirmou não ter projeto de licenciamento ambiental no local e disse estar dialogando com a comunidade.

Sobre a mineração na região do Parque Estadual da Serra do Brigadeiro, a CBA esclarece que possui direitos minerários na zona de amortecimento do Parque, ou seja, local onde já existem áreas antropizadas e passíveis de licenciamento ambiental. A companhia afirma também que não tem processo de licenciamento ambiental em andamento no local. Em relação às ameaças sofridas 
pelo Frei Gilberto, a CBA se solidariza com ele e repudia o envolvimento do nome da Companhia no caso. Sobre a audiência pública, a empresa esclarece não ter sido convidada a participar da reunião em Belisário (G1 - Zona da Mata, 2017).

A visibilidade e os atos de violência acabaram contribuindo para o maior envolvimento da comunidade no intuito de evitar a prática minerária, assim foram sendo realizados cada vez mais eventos como fóruns de discussão e a caminhada das águas com o intuito de unir a comunidade e reafirmar a posição contrária ao novo empreendimento (Figura 1).

Figura 1 - Caminhada das águas realizada em Belisário no ano de 2018.

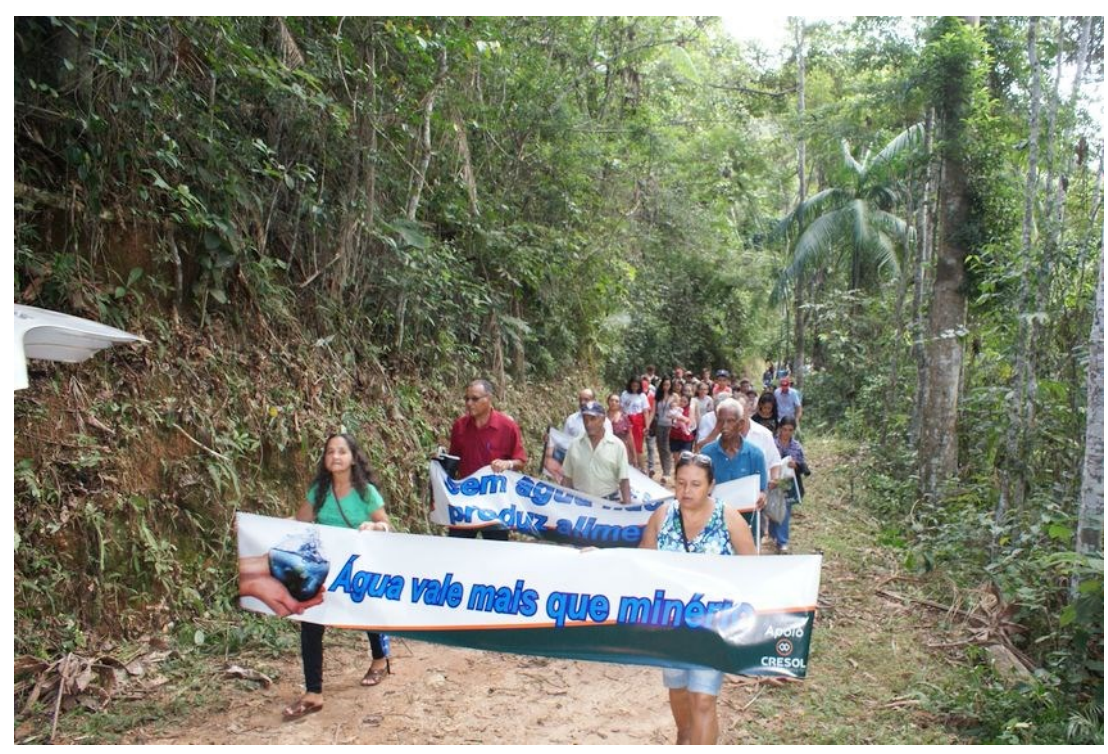

Fonte: Blog de Belisário-MG.

Segundo o Censo Demográfico do IBGE, Belisário possui apenas 2,31\% da população de Muriaé, porém tal mobilização conseguiu unir o município. Em 27 de novembro de 2018, a Câmara Municipal, aprovou um projeto do poder executivo, instituindo como Patrimônio Hídrico Municipal de Muriaé uma área de 10.215,07 hectares de áreas localizadas no distrito, deferindo em seu parágrafo único (Figura 02):

Deverão ser incentivadas pelo Poder Público, na área delimitada por esta Lei, a realização de atividades econômicas e sociais sustentáveis, como a prática do turismo natural ou ecológico, a agricultura familiar sustentável, a conservação ambiental e a promoção da pesquisa científica e educação ambiental, dentre outras práticas que colaborem na construção de uma política municipal de proteção aos recursos hídricos. (MURIAÉ, 2018). 
Figura 2 - Área considerada Patrimônio Hídrico Municipal de Muriaé no distrito de Belisário e o Parque Estadual da Serra do Brigadeiro.

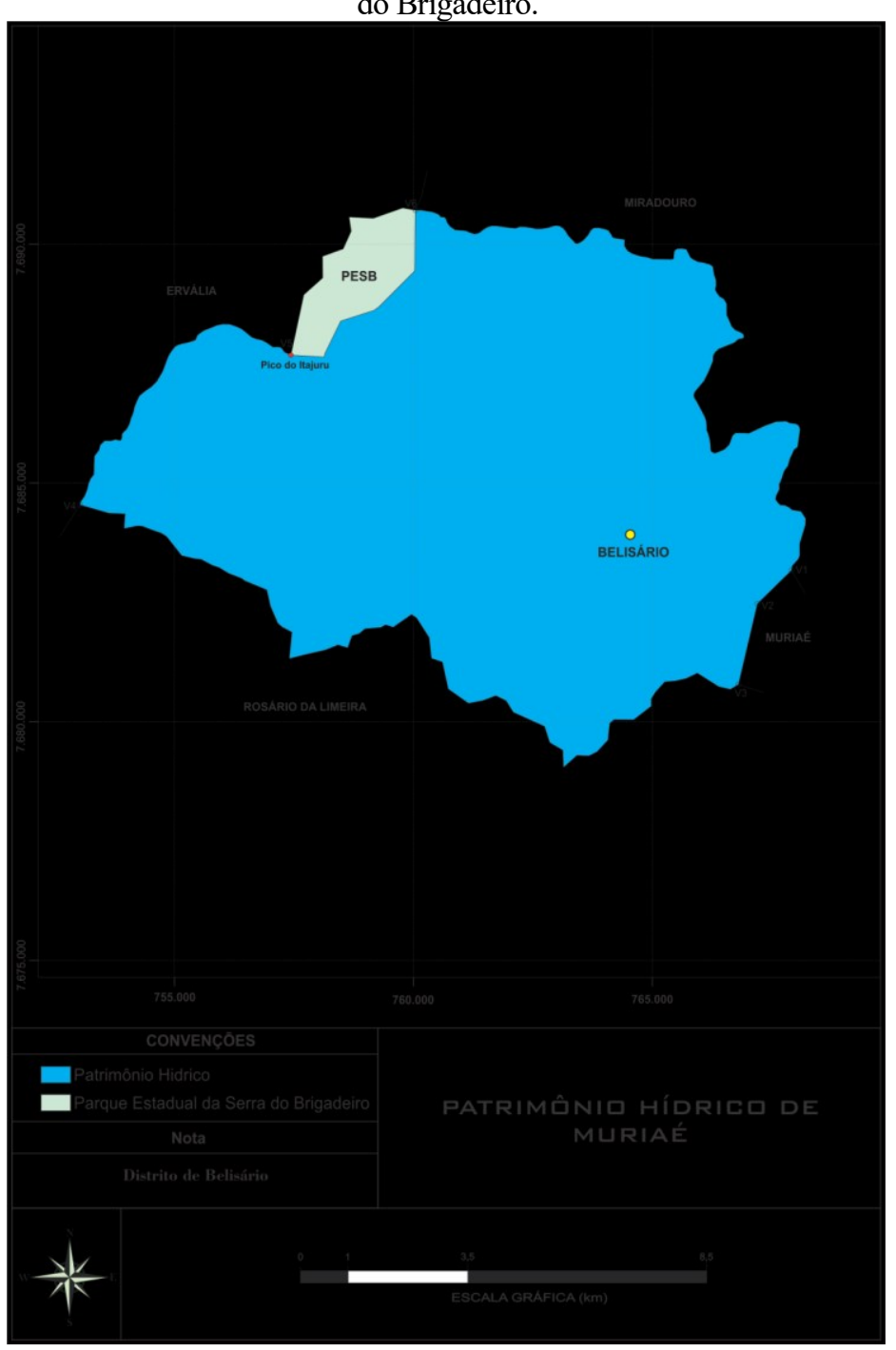

Fonte: Muriaé, 2018.

A aprovação da Lei $n^{0} 5.763 / 2018$ foi vista pela comunidade local e pela mídia local e regional como uma vitória contra a mineração, e ela realmente se estabelece como uma barreira para a CBA. A própria prefeitura divulgou em seu site uma reportagem com o seguinte título: "Belisário se torna Patrimônio Hídrico e está protegido contra a exploração mineral”. Porém, a empresa continua detendo os direitos minerários e pode em determinado momento tentar realizar o licenciamento ambiental e contornar a nova legislação municipal.

Encontramos em Belisário projetos distintos para a construção do território. De um lado está a mineradora com seu empreendimento capitalista, do outro lado a comunidade que vê estas mudanças como uma ameaça. Entretanto, não devemos partir da hipótese de que todas as pessoas têm a mesma opinião, visto que os interesses são diferentes e o poder de convencimento das campanhas publicitárias da empresa é enorme. 
Haesbaert (2004) apresenta três concepções de territórios que podem elucidar na compreensão da comunidade estudada:

1) Jurídico-político, segundo a qual o território é visto como um espaço delimitado e controlado sobre o qual se exerce determinado poder, especialmente de caráter estatal. 2) Cultural(ista), que prioriza dimensões simbólicas e mais subjetivas, o território visto fundamentalmente como produto da apropriação feita através do imaginário e/ou identidade social sobre o espaço. 3) Econômica, que destaca a desterritorização em sua perspectiva material, como produto espacial do embate entre classes sociais e da relação capital-trabalho. (HAESBAERT, 2004. p. 59).

Cazella et al., (2009) reforça essas concepções de território:

[...] Quatro concepções de território, não excludente entre si e que guardam estreita ligação com os olhares disciplinadores: a) território como unidade de atuação do estado para controlar a produção de externalidades pela agricultura, sejam elas positivas ou negativas; essa abordagem responde essencialmente a uma preocupação da economia política. b) território como unidade de construção de recursos específicos para o desenvolvimento econômico; essa preocupação corresponde ao ponto de vista da economia territorial; c) território como produto de uma ação coletiva, concepção relacionada à economia das organizações; d) território como componente fundamental das sociedades tradicionais, no sentido das sociedades arcaicas, que se inscreve na perspectiva da antropologia e da antropologia econômica. (CAZELLA et al., 2009, p. 51).

Este trabalho propõe identificar as intenções da comunidade sobre o projeto minerário, pois se o empreendimento for centrado exclusivamente na concepção 2 de Haesbaert (2004) e b de Cazzella et al., (2009) citados acima, podem resultar no enfraquecimento ou mesmo no fim das atuais peculiaridades do distrito, como a agricultura familiar e o turismo.

O foco se concentra, principalmente, nos jovens que estão próximos a adentrar no mundo do trabalho, visto que estes irão construir suas comunidades a partir de suas relações sociais e econômicas, devemos então pensar esta possibilidade da mineração, a partir dos impactos no lugar, considerando-o que a sua construção se dá a partir de escolhas, pois como afirma Milton Santos (2002):

[...] o lugar é o lugar de uma escolha. O mundo está aí e o lugar colhe no mundo atributos que o realizam histórica e geograficamente. É o mundo que se dá seletivamente no lugar. O fenômeno técnico, na sua abrangência telúrica atual, permite entender a totalidade-mundo a partir dessa empiricidade. Por conseguinte, a possibilidade de uma teorização que abrange o todo e a parte no campo do espaço se tornou possível também através, creio eu, e digo com toda a timidez, do cotidiano. Porque o cotidiano é a realização das pessoas e, quem sabe, também das instituições e das empresas nos lugares. (SANTOS, 2002, p. 70-71).

\section{DESENVOLVIMENTO}

\section{A Pesquisa}

Partimos da necessidade de pensar a materialidade histórica desta comunidade, sendo ela construída pelo trabalho humano ao longo de sua evolução. E como aborda Pires (1997) a lógica dialética 
do meterialismo histórico dialética vem no sentido de ser instrumento de construção e reflexão que resulta na elaboração de um pensamento pleno, ou seja, nos orienta nesta investigação, na medida que:

[...] movimentar o pensamento significa refletir sobre a realidade partindo do empírico (a realidade dada, o real aparente, o objeto assim como ele se apresentam à primeira vista) e, por meio de abstrações (elaboração do pensamento, reflexões, teoria), chegar ao concreto: compreensão mais elaborada do que há de essencial no objeto, objeto síntese de múltiplas determinações, concreto pensando. Assim, a diferença entre o empírico (real aparente) e o concreto (real pensado) são as abstrações (reflexões) do pensamento que tornam mais completa a realidade observada. (PIRES, 1997, p. 86).

Para alcançar os objetivos deste trabalho, o passo inicial foi buscar informações sobre o local de pesquisa e dos acontecimentos recentes, isto se deu através de contato e conversas informais com moradores; na busca de notícias sobre o distrito, principalmente as relacionadas à CBA; de informações demográficas através do IBGE; e de um levantamento bibliográfico acerca das questões legais e dos conceitos de território e lugar.

Após toda está contextualização e com o propósito de conhecer a posição dos jovens sobre a possibilidade da operação da mineração, foi aplicado um questionário para os 42 estudantes do $1^{\circ}$ e $2^{\circ}$ ano do ensino médio da Escola Estadual Pedro Vicente de Freitas, localizada na sede do distrito. O questionário foi confeccionado com questões abertas e fechadas que abordavam sobre o que eles pensavam sobre os possíveis impactos e consequências da possível instalação dessa nova atividade econômica.

Como o objetivo deste trabalho é obter elementos para avaliação de questões tão complexas na vida destes jovens, como por exemplo: as perspectivas sobre o modelo de comunidade a ser construída e o pertencimento deles no lugar, a aplicação do questionário foi muito além das respostas fechadas e os gráficos produzidos. Todas os depoimentos e expressões percebidas foram absorvidas e consideradas para produção da pesquisa.

\section{Questão Legal}

O histórico de ocupação do Brasil nos remete a um modelo predatório ao meio ambiente, onde a maioria das atividades econômicas geraram um grande ônus ambiental, basta lembrar da mineração e do intenso desmatamento para as práticas agrícolas. As legislações ambientais começaram a ser delineadas significativamente no Brasil apenas na década de 1930, motivadas principalmente pelo processo de industrialização brasileiro que levantava a necessidade de se pensar as demandas ambientais, porém o fator econômico ainda estava no centro das decisões como afirma Moura (2016): 
Nas décadas de 1930 a 1960 não havia propriamente uma política ambiental no Brasil ou uma instituição gestora da temática ambiental. Havia políticas setoriais que consideravam tangencialmente a questão ambiental, tendo como foco a exploração dos recursos naturais. A principal preocupação no período era a administração ou o "controle racional" dos recursos naturais, visando o melhor uso econômico.

Ao final da década de 1960, a temática ganhou impulso quando algumas demandas ambientais da sociedade começaram a surgir, tendo como precedente a poluição gerada por atividades produtivas, principalmente a poluição industrial. (MOURA, 2016, p. 14).

Ainda, segundo Moura (2016), na década de 1970 o Brasil deixou claro a sua posição a favor do desenvolvimento industrial e do crescimento econômico em detrimento das questões ambientais destacadas durante a Conferência de Estocolmo de 1972. Em 1973 o governo federal cria a Secretaria Especial de Meio Ambiente (SEMA) com uma agenda centrada na poluição industrial. Seguindo o modelo da União, estados como Rio de Janeiro e São Paulo criaram órgãos estaduais de meio ambiente.

A década e 1980 foi marcada por várias transformações políticas e sociais no Brasil com vários avanços em termos da criação e reformulação dos órgãos públicos federais, mas o maior destaque se deu com a promulgação da Constituição Federal de 1988, que em seu artigo 225 afirma: "Todos têm direito ao Meio Ambiente ecologicamente equilibrado, bem de uso comum do povo e essencial à sadia qualidade de vida, impondo-se ao Poder Público e à coletividade o dever de defendê-lo e preservá-lo para as presentes e futuras gerações".

Além de um artigo exclusivo para as questões ambientais a Constituição Federal de 1988 trouxe em vários outros pontos menções à importância da preservação ambiental e dos direitos ambientais. Para Moura (2016), na década de 1990 a questão ambiental avançou no Brasil, porém a passos lentos. Um destaque para a criação do Ministério do Meio Ambiente em 1992, que atuou por anos com grandes restrições orçamentárias e pequeno quadro de pessoal. Assim, o grande marco da década foi a criação da Lei de Crimes Ambientais (Lei ${ }^{0}$ 9.605/1998), fazendo o Brasil um dos primeiros países do mundo a possuir legislação penal ambiental.

O século XXI veio com grandes expectativas nas questões ambientais, pois em várias conferências internacionais com o tema Meio Ambiente, este foi proclamado como o século da mudança. No Brasil não houve grandes transformações práticas, os conflitos ambientais ainda são realidade em diversos locais, mas ocorreram ganhos em questões legais, como podemos observar no quadro 1. 
Quadro 1 - Legislação Ambiental Brasileira de 1930 a 2015.

LEGISLAÇÃO

Decreto $n^{\circ} 24.643 / 1934$

Decreto-Lei n ${ }^{\circ} 25 / 1937$

Lei $n^{\circ} 6.225 / 1975$

Decreto-Lei $n^{\circ} 1.413 / 1975$

Decreto Legislativo n ${ }^{\circ} 56 / 1975$

Lei ${ }^{\circ} 6.453 / 1977$

Lei $n^{\circ} 6.803 / 1980$

Lei $n^{\circ} 6.938 / 1981$

Lei $n^{\circ} 7.661 / 1988$

Lei $n^{\circ} 7.347 / 1985$

Lei $\mathrm{n}^{\circ} 7.805 / 1989$

Lei $n^{\circ} 7.797 / 1989$

Lei $n^{\circ} 7.802 / 1989$

Lei $n^{\circ} 8.171 / 1991$

Lei ${ }^{\circ} 8.723 / 1993$

Lei $n^{\circ} 8.974 / 1995$

Lei ${ }^{\circ} 9.433 / 1997$

Lei $n^{\circ} 9.605 / 1998$

Lei $n^{\circ} 9.795 / 1999$

Lei $n^{\circ} 9.985 / 2000$
EMENTA

\section{Décadas de 1930 a 1960}

Decreta o Código de Águas

Organiza a proteção do patrimônio histórico e artístico nacional. Inclui como patrimônio nacional os monumentos naturais, sítios e paisagens de valor notável

\section{Década de 1970}

Dispõe sobre discriminação, pelo Ministério da Agricultura, de regiões para execução obrigatória de planos de proteção ao solo e de combate à erosão e dá outras providências

Dispõe sobre o controle da poluição do meio ambiente provocada por atividades industriais

Aprova o Tratado da Antártida

Dispõe sobre a responsabilidade civil por danos nucleares e a responsabilidade criminal por atos relacionados com atividades nucleares e dá outras providencias

\section{Década de 1980}

Dispõe sobre as diretrizes básicas para o zoneamento industrial nas áreas críticas de poluição, e dá outras providências

Dispõe sobre a criação de Estações Ecológicas, Áreas de Proteção Ambiental e dá outras providências

Institui o Plano Nacional de Gerenciamento Costeiro e dá outras providências

Disciplina a ação civil pública de responsabilidade por danos causados ao meio ambiente, ao consumidor, a bens e direitos de valor artístico, estético, histórico, turístico e paisagístico e dá outras providências

Regulamenta as atividades garimpeiras, tornando obrigatória a licença ambiental prévia e passíveis de suspensão as atividades de pesquisa ou lavra que causarem danos ao meio ambiente

Cria o Fundo Nacional do Meio Ambiente (FNMA)

Dispõe sobre a pesquisa, a experimentação, a produção, a embalagem e rotulagem, o transporte, o armazenamento, a comercialização, a propaganda comercial, a utilização, a importação, a exportação, o destino final dos resíduos e embalagens, o registro, a classificação, o controle, a inspeção e a fiscalização de agrotóxicos, seus componentes e afins, e dá outras providências

\section{Década de 1990}

Dispõe sobre a política agrícola (inclui a proteção do meio ambiente entre seus objetivos e como um de seus instrumentos) Dispõe sobre a redução de emissão de poluentes por veículos automotores

Estabelece normas para a engenharia genética e organismos geneticamente modificados (OGM) no país

Institui a Política Nacional de Recursos Hídricos e cria o Sistema Nacional de Gerenciamento de Recursos Hídricos Dispõe sobre as sanções penais e administrativas derivadas de condutas e atividades lesivas ao meio ambiente, e dá outras providências

Dispõe sobre a educação ambiental e institui a Política Nacional de Educação Ambiental

Século XXI (2000 a 2015)

Institui o Sistema Nacional de Unidades de Conservação da Natureza (SNUC) 
Lei $n^{\circ} 9.966 / 2000$

Medida Provisória nº 2.186/-16/2001

Lei ${ }^{\circ} 10.650 / 2003$

Lei $n^{\circ} 11.105 / 2005$

Lei $n^{0} 11.284 / 2006$

Lei $\mathrm{n}^{\circ} 11.428 / 2006$

Lei ${ }^{\circ} 11.445 / 2007$

Lei ${ }^{\circ} 11.460 / 2007$

Lei ${ }^{\circ}$ 11.794/2008

Lei ${ }^{\circ} 11.828 / 2008$

Lei n ${ }^{\circ} 11.959 / 2009$

Lei $\mathrm{n}^{\mathrm{o}} 12.114 / 2009$

Lei $n^{\circ} 12.187 / 2009$

Lei $\mathrm{n}^{\circ} 12.305 / 2010$

Lei Complementar no 140/2011

Lei $\mathrm{n}^{\mathrm{o}} 12.512 / 2011$

Lei $n^{\circ} 12.651 / 2012$

Lei ${ }^{\circ} 13.153 / 2015$
Dispõe sobre a prevenção, o controle e a fiscalização da poluição causada por lançamento de óleo e outras substâncias nocivas ou perigosas em águas sob jurisdição nacional Dispõe sobre o acesso ao patrimônio genético, a proteção e o acesso ao conhecimento tradicional associado, a repartição de benefícios e o acesso à tecnologia e transferência de tecnologia para sua conservação/ e utilização.

Dispõe sobre o acesso público aos dados e às informações existentes nos órgãos e entidades integrantes do SISNAMA

Estabelece normas de segurança e mecanismos de fiscalização de atividade que envolvam OGMs e derivados, cria o Conselho Nacional de Biossegurança (CNBS), reestrutura a Comissão Técnica Nacional de Biossegurança (CTNBio) e dispõe sobre a Política Nacional de Biossegurança (PNB)

Dispõe sobre a gestão de floresta públicas para a produção sustentável: institui, na estrutura do MMA, o Serviço Florestal Brasileiro (SFB); cria o Fundo Nacional de Desenvolvimento Florestal (FNDF)

Dispõe sobre a utilização e proteção da vegetação nativa do Bioma Mata Atlântica

Estabelece diretrizes nacionais o saneamento básico

Dispõe sobre o plantio de organismos geneticamente modificados em Unidades de Conservação (UCs)

Estabelece procedimentos para uso científico de animais

Trata de medidas tributárias aplicáveis a doações destinadas a prevenção, monitoramento e combate ao desmatamento

Dispõe sobre a Política Nacional de Desenvolvimento Sustentável da Aquicultura e da Pesca

Cria o Fundo Nacional sobre Mudança do Clima Institui a Política Nacional sobre Mudanças do Clima (PNMC) Institui a Política Nacional de Resíduos Sólidos (PNRS)

Fixa normas para a cooperação entre União, Estados, Distrito Federal e os municípios nas ações administrativas decorrentes do exercício da competência comum relativa à proteção do meio ambiente

Institui o Programa de Apoio à Conservação Ambiental e o Programa de Fomento às Atividades Produtivas Rurais

Dispõe sobre a proteção da vegetação nativa (revogou o antigo Código Florestal, Lei n ${ }^{\circ}$.771/1965)

Institui a Política Nacional de Combate a Desertificação e Mitigação dos Efeitos da Seca e seus instrumentos; prevê a criação da Comissão Nacional de Combate à Desertificação

Fonte: Adaptado de Moura, 2016.

As legislações ambientais a partir do estabelecido na Constituição Federal de 1988 também se desenvolveram nas esferas estaduais e municipais, porém estas não foram suficientes para eliminar os conflitos ambientais brasileiros.

Para compreendermos a importância da preservação ambiental para o distrito de Belisário devemos partir dos objetivos dos projetos de preservação existentes na comunidade. O Parque Estadual 
Serra do Brigadeiro (Figura 03), Unidade de Conservação gerenciada pelo Instituto Estadual de Floresta de Minas Gerais (IEF/MG), os parques estaduais mineiros têm como objetivo:

A preservação de ecossistemas naturais de grande relevância ecologia e beleza cênica, possibilitando a realização de pesquisas científicas e o desenvolvimento de atividades de educação e interpretação ambiental, de recreação em contato com a natureza e de turismo ecológico. Pertence à categoria de unidades de conservação integral e é de posse e domínio públicos.

\section{Ainda segundo o IEF/MG o Parque Estadual da Serra do Brigadeiro foi criado a partir do Decreto}

n 38.318 de 27 de setembro de 1996, e é de grande relevância ambiental e social na região, pois:

É uma das mais importantes reservas naturais de Minas Gerais, ocupando o extremo norte da Serra da Mantiqueira, entre os vales do Rio Carangola, Gloria e Rio Doce.

A Serra do Brigadeiro possui inúmeras nascentes, que contribuem de maneira significativa para a formação de duas importantes bacias hidrográficas do estado: Rio Doce e Paraíba do Sul.

Caracterizado pela Floresta Atlântica de Encosta e por Campos de Altitude, o parque possui grande importância na preservação destes dois biomas. A serra é considerada um paraíso botânico, por abrigar espécies raras e ainda não catalogados pela ciência. No parque existe uma neblina, que se mantém quase o ano todo encobrindo as serras e picos.

Os primeiros habitantes na Zona da Mata, onde se localiza o parque, foram os índios Puris, Coroados e Coropós. Conhecida por diversos nomes ao longo do tempo, a Serra do Brigadeiro era conhecida originalmente como Serra dos Arrepiados, referindo-se, segundo versões diferentes, os cabelos amarrados em forma de coque dos índios Puris, ou ao frio das terras altas, que arrepiava a pele daqueles que por lá passavam.

Figura 3 - Território do Parque Estadual da Serra do Brigadeiro.

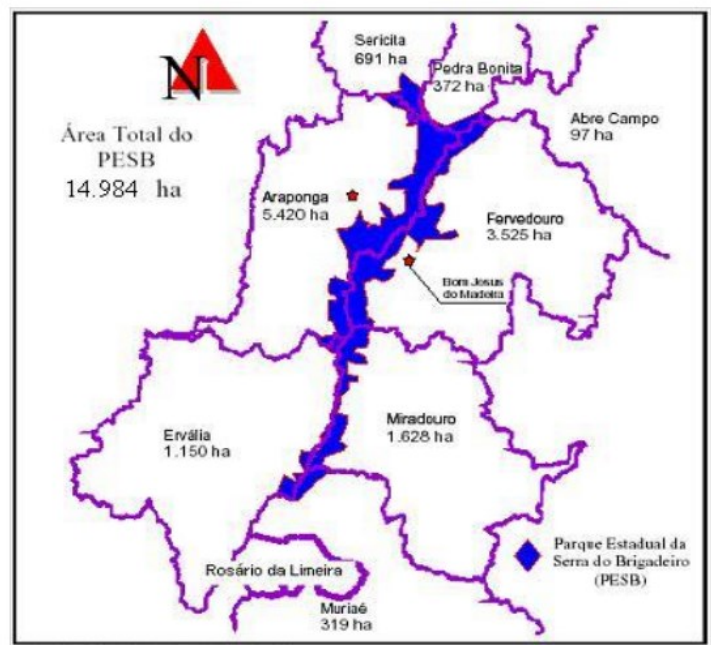

Fonte: MAFFIA, 2013.

A Área de Preservação Ambiental Municipal Pico do Itajurú (Figura 04), também está localizada dentro do parque, mas foi instituída pelo poder público municipal a partir da Lei no 2.110/1997, criando uma área de preservação permanente, deixando claro no artigo $2^{\circ}$ que a destinação destas terras devem ser apenas para: a) proteção e preservação da flora, fauna e demais recursos naturais com utilização para objetivos científicos e educacionais; b) assegurar condições de bem estar público e controle ambiental. 
Figura 4 - Vista do Pico do Itajurú - Belisário, distrito de Muriaé.

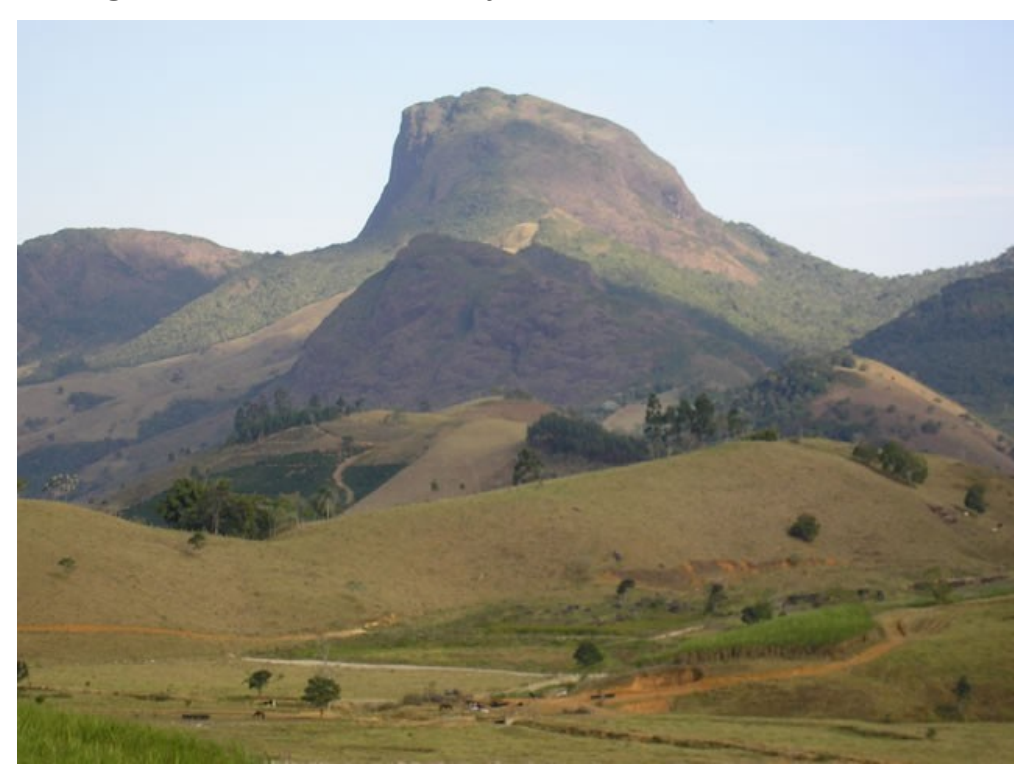

Fonte: Blog minasgerais.com.br.

Além da criação e manutenção das Unidades de Conservação é indispensável criar programas de manejo para as áreas próximas, pois estes territórios muitas vezes possuem ocupações históricas por comunidades que sempre desenvolveram suas atividades sociais e econômicas nestas áreas. Surge assim, as Zonas de Amortecimento, definida por lei federal como área no entorno de uma Unidade de Conservação, onde as atividades humanas estão sujeitas a normas e restrições especificas, com o propósito de minimizar os impactos negativos sobre a unidade (BRASIL, 2000).

É justamente nas zonas de amortecimento do distrito de Belisário que a CBA tem projetos de mineração, mesmo local de ocupação histórica da comunidade que desenvolve as atividades agrícolas e mais recentemente o turismo.

\section{Território e Lugar}

Neste trabalho buscamos pensar o conceito de lugar na comunidade estudada a partir da perspectiva de Carlos (2007), pois ela destaca que a apropriação do espaço ocorre a partir das relações corporais e dos sentidos, que ocorre de maneira desigual dependendo das características do lugar onde, por exemplo, as relações ocorrentes em grandes centros urbanos serão diferentes das de pequenas vilas e cidades.

Como o homem percebe o mundo? É através de seu corpo de seus sentidos que ele constrói e se apropria do espaço e do mundo. O lugar é a porção do espaço apropriável para a vida - apropriada através do corpo - dos sentidos - dos passos de seus moradores, é o bairro é a praça, é a rua, e 
nesse sentido poderíamos afirmar que não seria jamais a metrópole ou menos a cidade latu sensu a menos que seja a pequena vila ou cidade - vivida/conhecida/reconhecida em todos os cantos. Motoristas de ônibus, bilheteiros, são conhecidos-reconhecidos como parte da comunidade, cumprimentados como tal, não simples prestadores de serviço. As casas comerciais são mais do que pontos de troca de mercadorias, são também pontos de encontro. É evidente que é possível encontrar isso na metrópole, no nível do bairro, que é o plano do vivido, mas definitivamente, não é o que caracteriza a metrópole. (CARLOS, 2007, p. 17).

Carlos (2007) propõe pensar o lugar analisando a tríade habitante, identidade e lugar, pois é neste contexto que ocorre todo tipo de relação entre o indivíduo e o espaço habitado. Neste contexto de iminência do avanço da mineração sobre o distrito de Belisário, pensar está tríade possibilita compreender qual o sentimento de pertencimento dos sujeitos desta pesquisa no lugar a partir dos posicionamentos sobre o novo empreendimento capitalista, que independente de seu tamanho e intensidade transformará o distrito, assim como os sentimentos de identidade e pertencimento de seus habitantes.

A organização popular ocorrida na comunidade estudada para impedir a prática minerária é fruto desta relação de pertencimento dos moradores com o lugar. Brandão (2009) aborda sobre o sentido de viver o espaço com a importância de ter dignidade, com o direito de ter esperança e sonhar. Muitas vezes as peculiaridades da existência, poderão possibilitar que o valor de uso, o valor imaterial, seja maior que um valor monetário, pois:

Habitar. Criar um lugar onde pessoas, famílias, grupos e comunidades reúnem-se para conviver. Nós, os humanos, tornamos habitável um espaço múltiplo - entre a horta caseira, a casa que acolhe a horta e a catedral que consagra as duas, não porque o levantamos do chão materialmente, mas porque realizamos isto, movidos por palavras e imagens, símbolos e sentidos, ideias e imaginários. E uma grande parte do labor e do trabalho de todos os dias está dirigida a criar e perpetuar os lugares que, uma vez construídos, tornam-se o "aqui" onde se vive e habita. Por isso uma casa velha e quase em ruínas é ainda um lugar ancestral e quanto mais velho entre gerações, mais ela é um "lar". Por isso, depois de construída e habitada, ela é mais - mesmo hoje, mesmo agora bem mais do que um bem material. Uma casa torna-se um dom de sentido: um patrimônio. Neste lugar onde eu moro o valor de troca (o quando ela vale em dinheiro) submete-se ao valor de uso (o quanto ela vale por ser onde eu habito) e, ambos, submetem-se ao valor do dom (o quanto ela vale como um símbolo chamado "a nossa casa"). Algo que acaba "não tendo preço", mesmo que financeiramente esteja “aos pedaços" e "não tenha valor”. (BRANDÂO, 2009, p. 20-21).

As escolhas desta comunidade sobre a chegada ou não da mineração, interferirão diretamente em qual concepção de território será construída. Belisário, apesar de suas peculiaridades, também está incluso em uma dinâmica global, basta destacar a cafeicultura para exportação amplamente desenvolvida no distrito. Caso ocorra o novo empreendimento, este território seria amplamente modificado, principalmente no que tange a implantação de infraestruturas, pois como aborda Santos e Silveira (2001), o Espaço Geográfico é sinônimo de "território usado" e este uso está centrado não apenas nas ações de grupos hegemônicos, mas também no "espaço banal”, aquele espaço do cidadão comum. 
Se restar para Belisário a concepção de território centrada exclusivamente no desenvolvimento econômico, provavelmente a mineração ditará os rumos para os próximos tempos Cazalla et al., (2009). É nesta concepção que a territorialidade pode ser uma alternativa para construção de um território que realmente atenda os anseios do cidadão comum, pois como afirma Santos e Silveira (2009):

\begin{abstract}
Por território entende-se geralmente a extensão apropriada e usada. Mas o sentido da palavra territorialidade como sinônimo de pertencer àquilo que nos pertence [...] esse sentido de exclusividade e limite ultrapassa a raça humana e prescinde da existência de estado. Assim, essa ideia de territorialidade se estende aos próprios animais, como sinônimo de área de vivência e de reprodução. Mas a territorialidade humana pressupõe também a preocupação com o destino, a construção do futuro, o que, entre os seres vivos, é privilégio do homem. (SANTOS e SILVEIRA, 2001, p. 19).
\end{abstract}

\title{
RESULTADOS
}

As perguntas do questionário não tinham como único objetivo elaborar dados numéricos, mas avaliar a sensibilidade dos estudantes para o problema. Além da aplicação do questionário, também foram considerados todos os momentos de convivência na busca da compreensão da realidade dos sujeitos da pesquisa.

Os alunos escolhidos entre aqueles que estão finalizando a etapa da educação básica e, em futuro próximo, entrarão no dilema de qual caminho seguir: fazer um curso superior ou técnico em Muriaé ou em outra cidade; trabalhar nas propriedades da família; entrar no mercado de trabalho urbano, tanto na sede do distrito ou do município, sem qualificação; trabalhar para terceiros em propriedade rurais. Neste contexto a atividade mineradora poderia se mostrar para estes jovens como um possível local de trabalho, podendo moldar opiniões favoráveis à nova atividade.

A primeira questão teve como objetivo compreender qual a relação deles com seu local de moradia. Podemos observar na figura 05 que a grande maioria mora a mais de 5 anos na comunidade, deixando evidente que Belisário não é um local de passagem para estas pessoas, mas sim um lugar de morada. 
Figura 5 - Há quanto tempo você reside no distrito de Belisário?

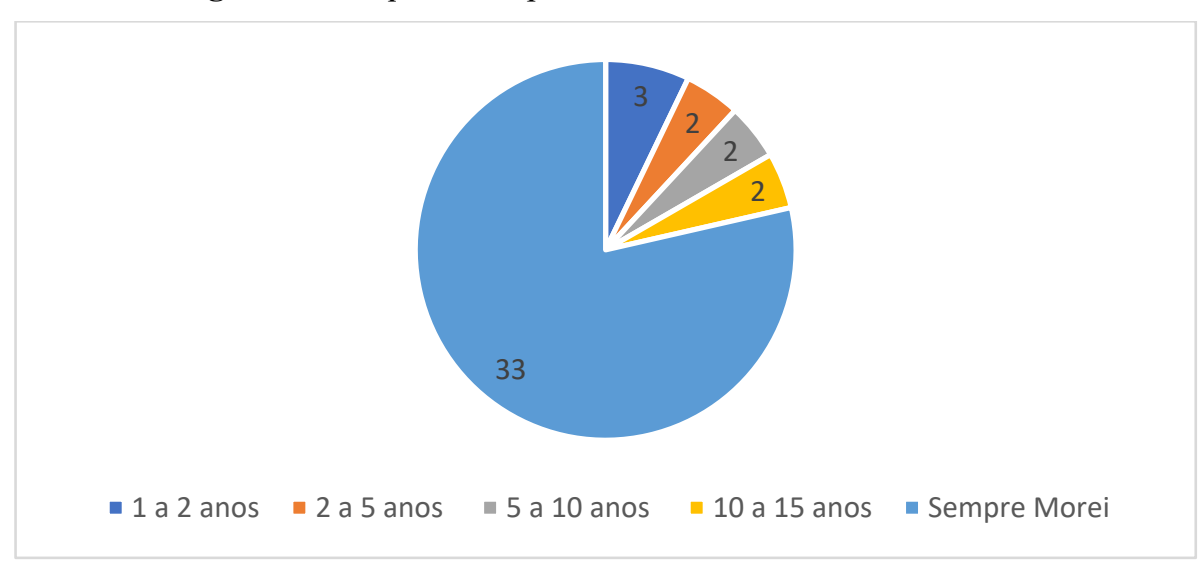

Além do tempo de moradia, constatamos também a importância da atividade agropecuária para estes sujeitos, pois $71 \%$ dos estudantes afirmaram que a principal atividade econômica de suas famílias era agrícola (Figura 6).

Figura 6 - A principal atividade econômica da sua família é?

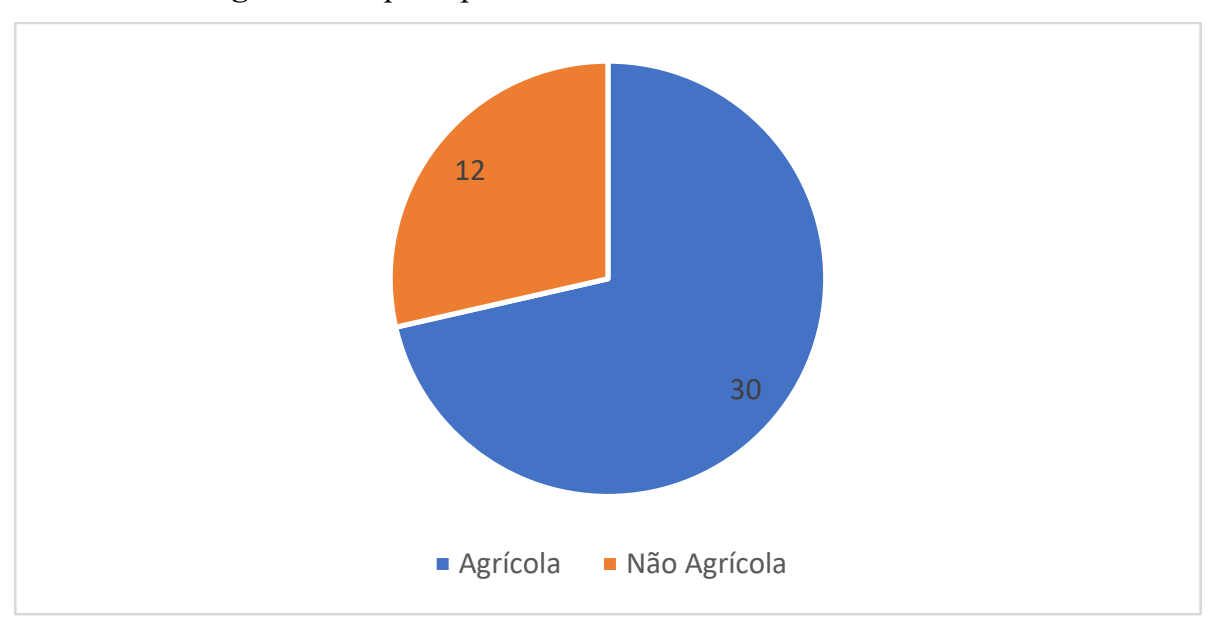

Sabendo do grande histórico dos estudantes com os locais de moradia, buscamos entender o conhecimento destes sobre a situação ambiental do distrito, a partir dos aspectos legais que resguardam parte do território de Belisário e, como ilustra a figura 7, vemos que muitos não tem uma consistente compreensão sobre as questões legais. 
Figura 7 - Você sabe o que é uma Unidade de Conservação?

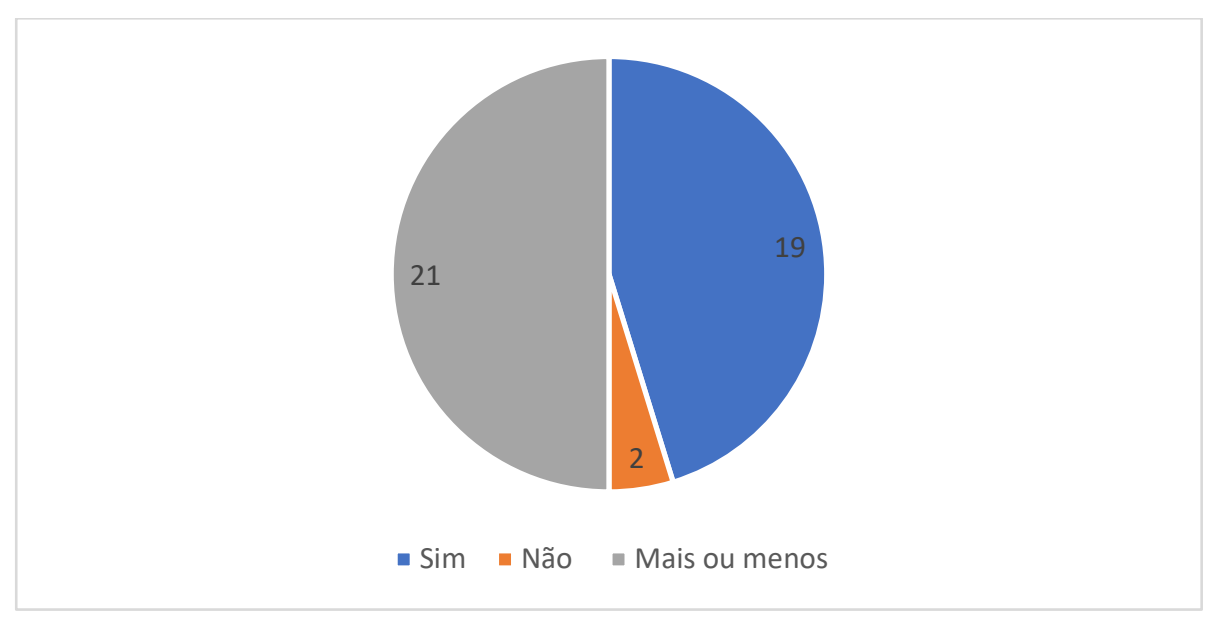

Mesmo não sabendo no fundo a real função de uma Unidade de Conservação, um número maior de estudantes tem conhecimento da existência da APA Pico do Itajurú e do Parque Estadual da Serra do Brigadeiro, como podemos ver nas figuras 08 e 09 . De certa forma isto pode ser explicado por elementos e situações existentes, que colocam os dois espaços em destaque, como placas de trânsitos turísticos, guias turísticos guiando visitantes e a própria presença de pessoas vinculadas aos órgãos públicos como o IEF/MG.

Figura 8 - Você tem conhecimento da existência da Área de Preservação Ambiental do Pico do Itajurú (APA Pico do Itajurú).

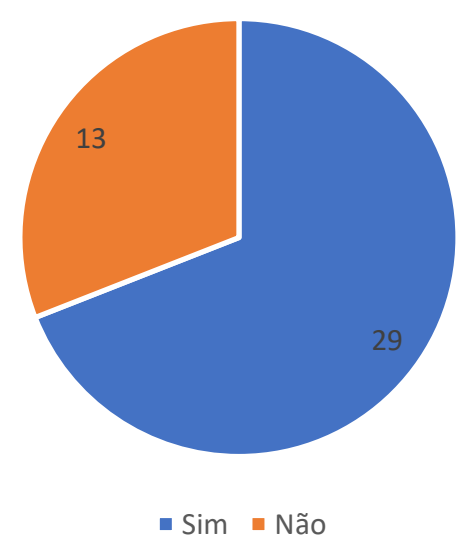


Figura 9 - Você tem conhecimento da existência do Parque Estadual da Serra do Brigadeiro.

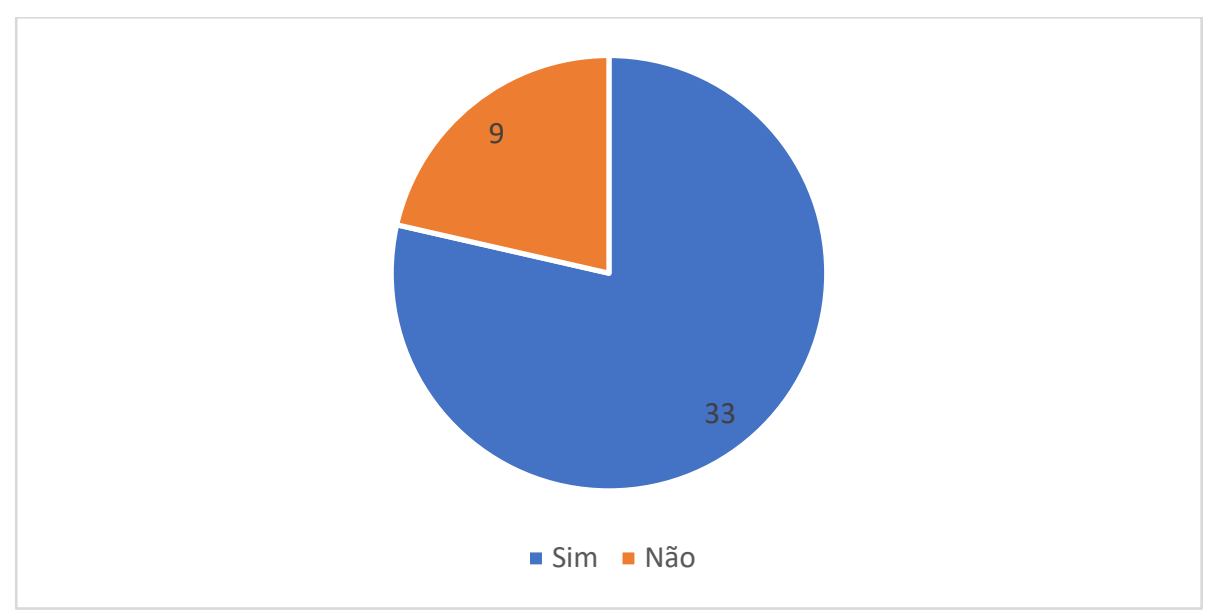

A repercussão da grande mobilização popular contrária a atividade mineradora e a própria ameaça de morte do Frei Gilberto, parece que atingiu quase que totalmente a estes jovens de Belisário, como podemos observar na figura 10. Vale lembrar que o espaço físico da escola foi utilizado para a realização de vários eventos que tinham como tema a mineração e os recursos hídricos em Belisário.

Figura 10 - Você tem conhecimento sobre o fato de empresas mineradoras terem projetos de mineração no distrito de Belisário?

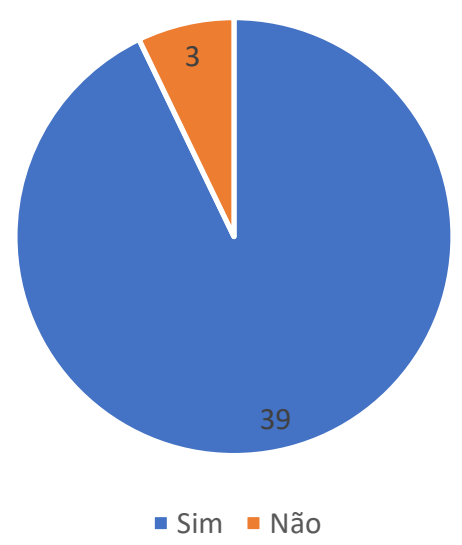

A lei municipal que transformou o distrito em Patrimônio Hídrico Municipal, apesar de ter sido amplamente divulgado pela imprensa e prefeitura e muito comemorada pelos setores da comunidade contrários à mineração ainda possui um número significativo de jovens que não tem conhecimento da sua existência, como se pode observar na figura 11. 
Figura 11 - Você sabia que Belisário se tornou Patrimônio Hídrico Municipal?

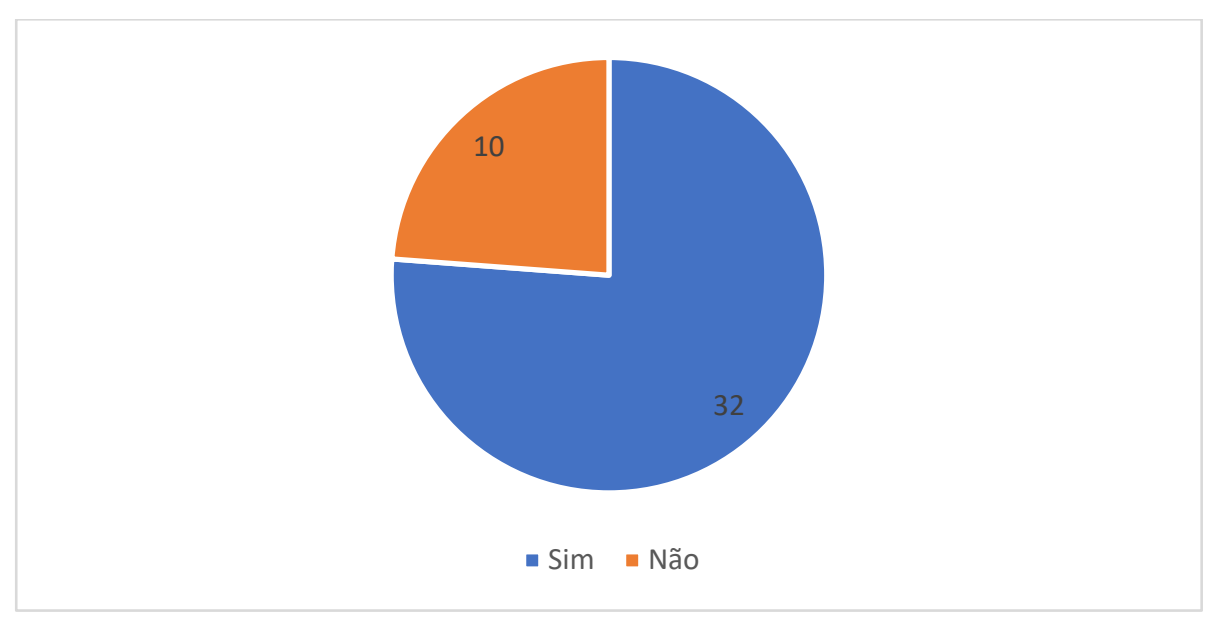

Quando questionados sobre os possíveis benefícios ou malefícios da mineração para a comunidade de Belisário, aos alunos responderam majoritariamente que haveria malefícios (Figura 12). Vários lembraram dos rompimentos de barragens nas cidades de Brumadinho e Mariana, ambas cidades em Minas Gerais, que foram amplamente divulgados pela imprensa nacional e internacional. Os comentários expressavam indignação, associando os rompimentos a crimes e falta de responsabilidade, isto pode explicar as respostas à pergunta, onde apenas dois alunos acreditam que a mineração traria mais benefícios do que malefícios.

Figura 12 - Se a mineração começasse em Belisário, você acha que ela traria mais.

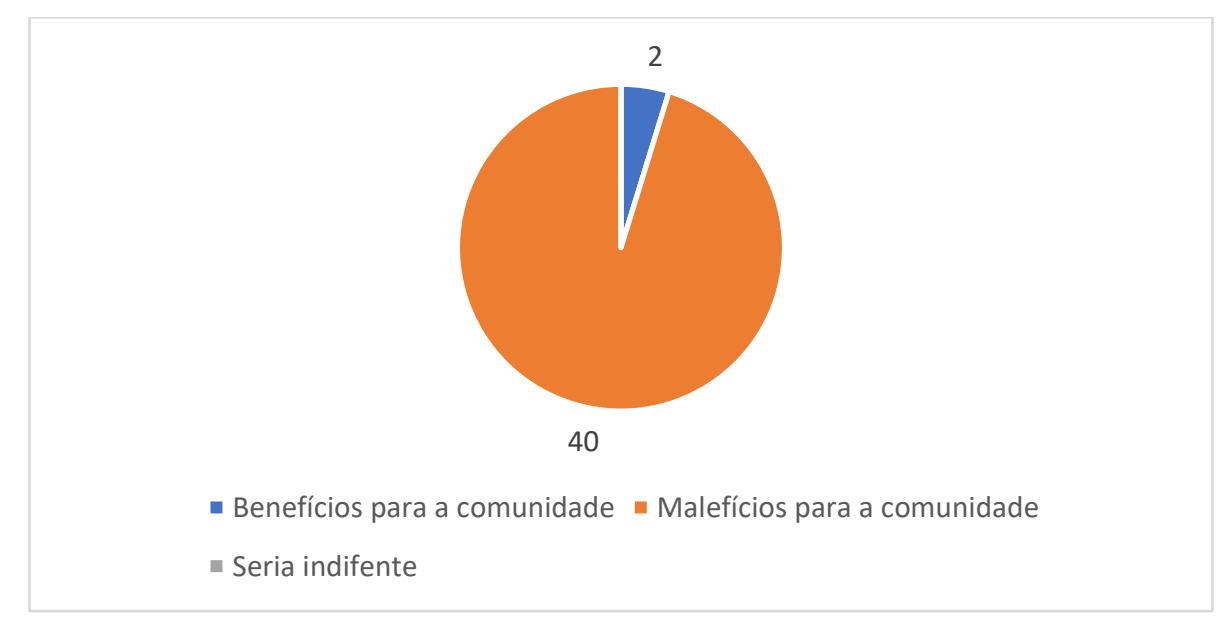

Os malefícios para a comunidade forma evidenciados principalmente na tradicional atividade agrícola do distrito e no crescimento do turismo, que nos últimos anos vem se mostrando como uma possível fonte de renda para moradores do distrito. Os estudantes não demostraram acreditar que a 
mineração pode ser desenvolvida sem prejudicar as atividades, como está evidenciado nas figuras 13 e 14.

Figura 13 - Você acredita que a mineração prejudicaria a atividade agropecuária do distrito de Belisário?

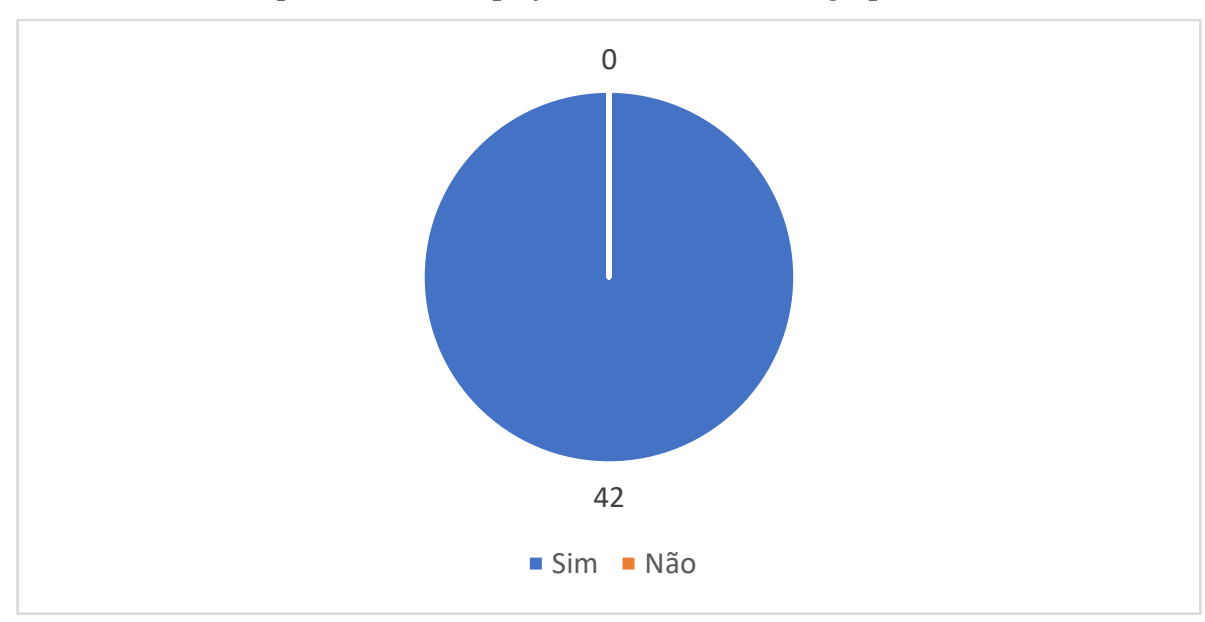

Figura 14 - Você acredita que a mineração prejudicaria a atividade de turismo do distrito de Belisário?

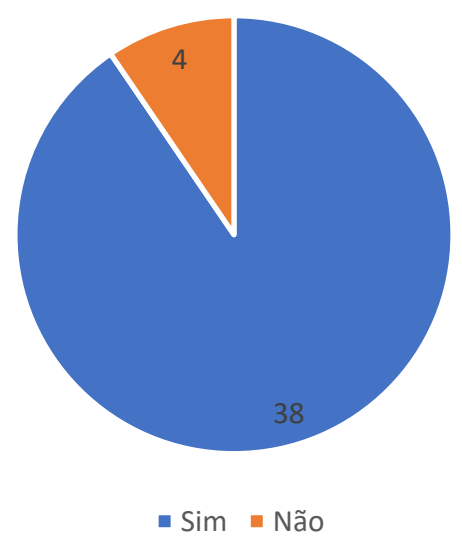

A hipótese de que os estudantes poderiam ver a mineração como opção de emprego, para quando estes entrassem no mercado de trabalho, foi contrariada na última pergunta objetiva do questionário, evidenciando que a maioria vê a mineração como um empreendimento externo que irá atuar em suas comunidades e que trarão benefícios principalmente para pessoas de fora, como podemos observar na figura 15. 
Figura 15 - Se a mineração começasse a operar no distrito de Belisário, qual das seguintes situações relacionadas ao mercado de trabalho você acredita que deverá ocorrer?

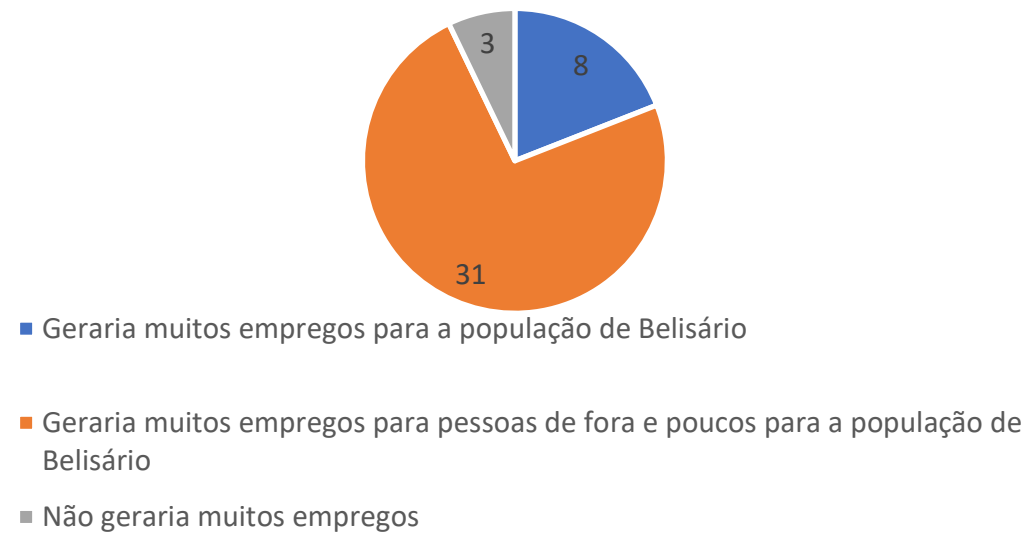

Além das perguntas objetivas, o questionário contou com duas perguntas onde os estudantes não tinham alternativas para as respostas, foi feita a seguinte pergunta: "Se houver, cite três possíveis benefícios que a atividade mineradora poderia trazer para o distrito de Belisário". Do total de 42 alunos, 27 afirmaram desconhecer qualquer possível benefício ou não responderam. Já dos 15 alunos restantes, nenhum conseguiu dar três exemplos, um citou que trará benefícios apenas para quem vender as terras para a mineradora, quatro citaram que gerará mais empregos para a comunidade, cinco afirmaram que poderá contribuir para a melhoria das estradas e outros quatro alunos mencionaram a criação de empregos e a melhoria das estradas. Vale lembrar que qualquer acesso ao distrito se dá por pelo menos $12 \mathrm{~km}$ de estrada sem pavimentação e nos comentários em sala no momento da aplicação, alguns afirmaram que as estradas deveriam ser asfaltadas para o fluxo de caminhões.

A segunda questão aberta do questionário foi a seguinte: "Se houver, cite três possíveis malefícios que a atividade mineradora poderia trazer para o distrito de Belisário". Nesta, os alunos conseguiram mais exemplos para suas respostas. 31 citaram três ou mais exemplos e apenas cinco não quiseram ou não conseguiram mencionar nenhuma. As respostas foram variadas, porém a grande maioria lembrou dos recursos hídricos, da agricultura e destruição do meio ambiente como um todo. Alguns alunos também citaram pontos interessantes como incentivo a prostituição, o risco de rompimento de barragens e o aumento nos acidentes de trânsito e de trabalho.

Foi frisado durante toda a aplicação do questionário, que a identificação do aluno não era objetivo da pesquisa, sendo desnecessário a assinatura e qualquer outra forma de identificação. Porém sete alunos ao final do questionário colocaram expressões com os seguintes dizeres: "MINERAÇÂO 
AQUI NÂO”; “\#MineraçãoAquiNão”; “SalveFreiGilberto!”. Essas palavras de ordens e hashtags foram e são amplamente utilizadas pelos movimentos contrários a mineração no distrito.

De todas as respostas para a última pergunta, uma conseguiu englobar o que estava expresso em vários outras, pois afirmou que:

\begin{abstract}
A mineração causaria o aumento do desmatamento e a destruição do meio ambiente, prejudicaria a saúde dos moradores de Belisário pela falta da flora, da fauna e da água, isto também atingiria o turismo. Prejudicaria o solo, pois tirando minério também se perderia os nutrientes orgânicos, deixando o solo pobre prejudicando a agricultura. Ou seja, a mineração causa sérios danos. MINERAÇÂO AQUI NÂO! (Resposta de um estudante ao questionário)
\end{abstract}

\title{
CONSIDERAÇÕES FINAIS
}

O desenvolvimento desta pesquisa foi bem-sucedida no intuito de compreender qual a visão que os jovens de Belisário têm sobre a possibilidade do desenvolvimento da mineração. Onde os questionários com questões abertas e fechadas serviu para eles expressarem seus anseios, assim como as falas e expressões capitadas ao longo do contato com os sujeitos.

Foi possível perceber que estes jovens têm algumas demandas por benéficos que a mineração pode trazer, como a possibilidade de emprego e a melhoria nas estradas de acesso, que atualmente é um grande transtorno para a comunidade a qual eles anseiam por melhorias.

Mas o que se destacou nos questionários e nas observações, é que estes estudantes estão mais preocupados com os malefícios que a mineração poderá trazer para a comunidade. Eles consideram que as peculiaridades do local de morada podem ser modificadas, principalmente as atividades agrícolas e o iminente turismo.

A relação de pertencimento com o lugar ficou evidenciada e para estes jovens não parece interessante um projeto para o distrito que considera a mineração como alternativa. A própria expressão "Mineração aqui não" lembrada por alguns ilustra que para eles o futuro de Belisário, deve depender de suas peculiaridades e não de um empreendimento externo que nos últimos anos vem se mostrando perverso para muitas comunidades, como ocorreu em Bento Rodrigues (Mariana) e no Córrego do Feijão e seu entorno (Brumadinho), ambas atingidas pelo rompimento de barragens de mineradoras.

A concepção de território que parece viável para estes jovens é aquela centrada na territorialidade no sentido de "pertencer a aquilo que nos pertence" exemplificada por Santos e Silveira (2001). Um território onde a mineração atuaria com agente principal, não atenderia aos anseios desta comunidade, mesmo que para alguns a atividade poderia trazer algum benefício, como um emprego próximo de casa. 
Belisário se organizou para evitar a atividade mineradora, os mais jovens também possuem está posição, evidenciado que para eles o "valor de uso" é mais importante que o "valor de troca" (BRANDÂO, 2009). Resta ao Estado garantir o direito de escolha destes cidadãos, proporcionando ao distrito um projeto de desenvolvimento centrado em suas peculiaridades e não na atividade mineradora.

\section{REFERÊNCIAS}

BRANDÃO, C. R. No Rancho Fundo: espaços e tempos no mundo rural. Uberlândia: EDUFU, 2009. $244 \mathrm{p}$.

BRASIL. Constituição Federal de 1988, de 5 de outubro de 1988. Disponível em: http:www.planalto.gov.br/ccivil_03/constituicao/constituicao.htm. Acesso em: 02 de outubro de 2019.

BRASIL. Lei $\mathbf{n}^{\mathbf{0}} \mathbf{9 . 9 8 5}$, de 18 de julho de 2000 . Disponível em: http://www.planalto.gov.br/ccivil_03/leis/L9985.htm. Acesso em: 10 de outubro de 2019.

CARLOS, A. F. A. O lugar no/do mundo. São Paulo: FFLCH, 2007. 85 p.

CAZElla, A. A.; BONNAL, P.; MALUF, R. S. Políticas de desenvolvimento territorial e multifuncionalidade da agricultura familiar no Brasil.

MALUF, R. S. (Org.) Agricultura Familiar Multifuncionalidade e Desenvolvimento Territorial no Brasil. Rio de Janeiro: Mauad X, 2009. p. 71-111.

DOTTA, R. Moradores de Muriaé (MG) barram mineração e transformam área em Patrimônio Hídrico. 2018. Disponível em: http://www.brasildefato.com.br/2018/12/12/moradores-de-muriar-mgbarram-mineracao-e-transformam-area-em-patromonio-hidrologico. Acesso em: 21 de outubro de 2019.

IEF-MG. Parque Estadual. Disponível em: http://www.ief.mg.gov.br/component/content/197?task. Acesso em: 25 de outubro de 2019.

IEF-MG. Parque estadual Serra do Brigadeiro. Disponível em: http://www.ief.mg.gov.br/component/content/197?task=view. Acesso em: 25 de outubro de 2019.

G1 - ZONA DA MATA. Frei ameaçado de morte em Muriaé é incluído em programa de proteção. Disponível em: https:/g1.globo.com/mg/zona-da-mata/noticia/frei-ameacado-de-morte-em-muriae-eincluido-em-programa-de-protecao.ghtml. Acesso em: 8 de outubro de 2019.

HAESBAERT, R. O mito da desterritorialização: do "fim dos territórios" à multiterritorialidade. Rio de Janeiro: Bertrand Brasil, 2004. 396 p.

IBGE. Instituto Brasileiro de Geografia e Estatística. Censo Demográfico de 2010. Disponível em: http://censo2010.ibge.gov.br/sinopseporsetores. Acesso em: 25 de setembro de 2019. 
KRAKOVICS, F. Exploração de minério enfrenta resistência de moradores em distrito de Minas. 2017. Disponível em: http://oglobo.com/brasil/exploracao-de-minerio-enfrenta-resistencia-demoradores-em-distrito-de-minas-21083328. Acesso em: 05 de outubro de 2019.

MAFFIA, A. M. C. Entorno do Parque Estadual da Serra do Brigadeiro: bauxita versus uso tradicional da terra. Tese (Doutorado em Ciência Florestal), Universidade Federal de Viçosa, 2013.

MOURA, A. M. M. Trajetória da Política Federal no Brasil. In: MOURA, A. M. M. (Org.) Governança Ambiental no Brasil: instituições, atores e políticas públicas. Brasília: IPEIA, 2016. p. 13-44.

MURIAÉ. Lei 2.110 de 12 de agosto de 1997. Disponível em: http://www.camaramuriae.mg.gov.br/images/leis/lei-n-2.2140.1997. Acesso em: 15 de outubro de 2019.

MURIAÉ. Lei 5.763 de 28 de novembro de 2018. Disponível em: http://camaramuriae.mg.gov.br/portal/leis-municipais/leis-municipais. Acesso em: 15 de outubro de 2019.

PIRES, M. F. C. O materialismo histórico-dialético e a educação. Interface - Comunicação, Saúde, Educação, v. 1, n. 1, p. 83-94, 1997.

SANTOS, M. Natureza do espaço: técnica e tempo, razão e emoção. São Paulo: Ática \& Ática, 2002. $392 \mathrm{p}$.

SANTOS, M.; SILVEIRA, M. L. O Brasil: território e sociedade no início do século XXI. Rio de Janeiro: Record, 2001. $476 \mathrm{p}$. 